by C. Stuart Houston, 863 University Drive, Saskatoon

Beginning in a small way with six birds banded in 1928 and four in 1929 , Fred G. Bard soon increased the tempo of his banding until his peak year of 1938 when he banded 1925 birds of 46 species. His father, Fred Bard, Sr., had a subpermit between 1939 and 1948 and banded 717 individuals of 33 species, and at times Bard was also assisted by members of the Museum staff. There was little opportunity for banding during the war years and the pressure of museum work caused little banding to be done after 1950, three years after Bard became director of the Saskatchewan Museum of Natural History.

Bard's all - time banding totalled 13,363 individuals of 103 species. One important activity was waterfowl banding, much of it in cooperation with Ducks Unlimited, with 3549 ducks, geese and coots banded. An equally important contribution was the banding of colonial birds. For this purpose, Bard visited Big Quill Lake, eight miles north of Dafoe, in 1931, 1932 and 1935; Big Quill, two miles north of Kandahar, in 1936 and 1937; Last Mountain Lake east of Holdfast in 1937; the north end of Last Mountain Lake in 1934, 1936, 1938, 1939, 1940, $1948,1949,1950$, and 1952; Old Wives Lake in 1958. In his active years, these banding totals surpassed and the number of recoveries far exceeded, those of any other bander in Saskatchewan. For the tabulation in Table 1 of banding and recoveries by species, all but the waterfowl recoveries have been verified by computer printout.

I have mapped the following: White Pelicans banded at Quill Lake, White Pelicans banded at Last Mountain Lake, Double-crested C or mor a n t s banded at Quill Lake, Double-crested Cormorants banded at Last Mountain Lake 1934-37 and Double-crested Cormorants banded at Last Mountain

* No. 13 in a series of biographies of Saskatchewan bird banders.
Table 1. Summary of bird banding by F. G. Bard.

\begin{tabular}{|c|c|c|c|}
\hline Species & 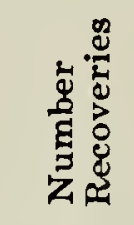 & 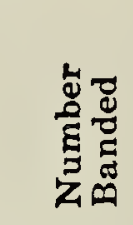 & 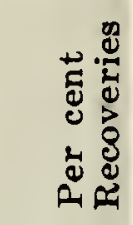 \\
\hline White Pelican & 958 & 86 & $9.0 \%$ \\
\hline \multicolumn{4}{|l|}{ Double-crested } \\
\hline Cormorant & 2038 & 371 & $18.5 \%$ \\
\hline Great Blue Heron & 31 & 2 & \\
\hline \multicolumn{4}{|l|}{ Black-crowned } \\
\hline Night Heron & 21 & 1 & \\
\hline Canada Goose .... & 196 & 14 & $7.2 \%$ \\
\hline Mallard & 2570 & 404 & $15.8 \%$ \\
\hline Gadwall & 49 & 8 & $16.3 \%$ \\
\hline Pintail & 196 & 59 & $30.0 \%$ \\
\hline Blue-winged Teal & 300 & 8 & $2.7 \%$ \\
\hline American Widgeon & 81 & 9 & $11.1 \%$ \\
\hline Shoveler ................ & 60 & 3 & $5.0 \%$ \\
\hline Lesser Scaup & 15 & 2 & \\
\hline Ferruginous Hawk & 4 & 1 & \\
\hline Marsh Hawk ........ & 24 & 3 & $12.5 \%$ \\
\hline \multicolumn{4}{|l|}{ Sharp-tailed } \\
\hline Grouse & 28 & 1 & \\
\hline American Coot & 42 & 1 & \\
\hline Killdeer ... & 26 & 1 & \\
\hline Ring-billed Gull . & 2408 & 110 & $4.6 \%$ \\
\hline Franklin's Gull .... & 270 & 3 & $1.1 \%$ \\
\hline Common Tern ...... & 1244 & 2 & $.2 \%$ \\
\hline Mourning Dove. & 80 & 1 & \\
\hline \multicolumn{4}{|l|}{ Yellow-shafted } \\
\hline Flicker & 77 & 3 & $\%$ \\
\hline Eastern Phoebe .... & 6 & 1 & \\
\hline Tree Swallow ........ & 22 & 1 & \\
\hline Barn Swallow ...... & 49 & 3 & $6.1 \%$ \\
\hline \multicolumn{4}{|l|}{ Black-billed } \\
\hline Magpie & 90 & 24 & 26.67 \\
\hline Common Crow ...... & 781 & 167 & $21.7 \%$ \\
\hline House Wren .......... & 249 & 1 & \\
\hline Catbird & 205 & 4 & $2.0 \%$ \\
\hline Brown Thrasher .. & 63 & 3 & $4.8 \%$ \\
\hline Robin & 160 & 5 & $3.1 \%$ \\
\hline Cedar Waxwing.... & 85 & 1 & \\
\hline Yellow Warbler .... & 64 & 1 & \\
\hline \multicolumn{4}{|l|}{ Red-winged } \\
\hline Blackbird & 90 & 2 & \\
\hline Common Grackle.. & 128 & 16 & $12.4 \%$ \\
\hline 68 other species ... & 653 & 0 & \\
\hline TOTAL & 63 & 1322 & 9.8 \\
\hline
\end{tabular}




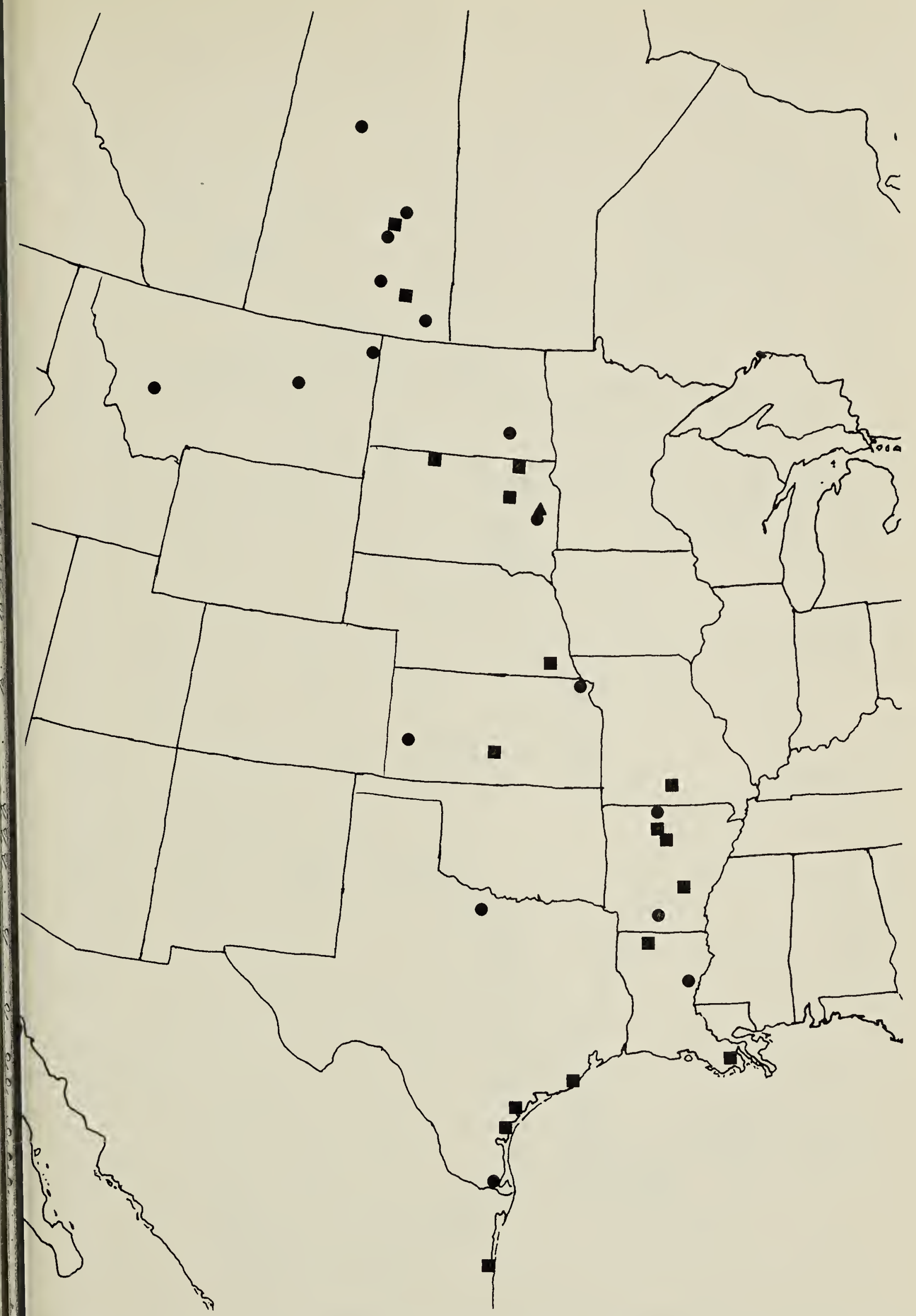

Fig. 1. Recoveries of White Pelicans banded at Quill Lake by Fred G. Bard, 1931, 1932, 1933, 1936, 1937. Note: squares represent direct recoveries same year); triangles - January 1 to June 30 of the following year; circles nore than one year old. 


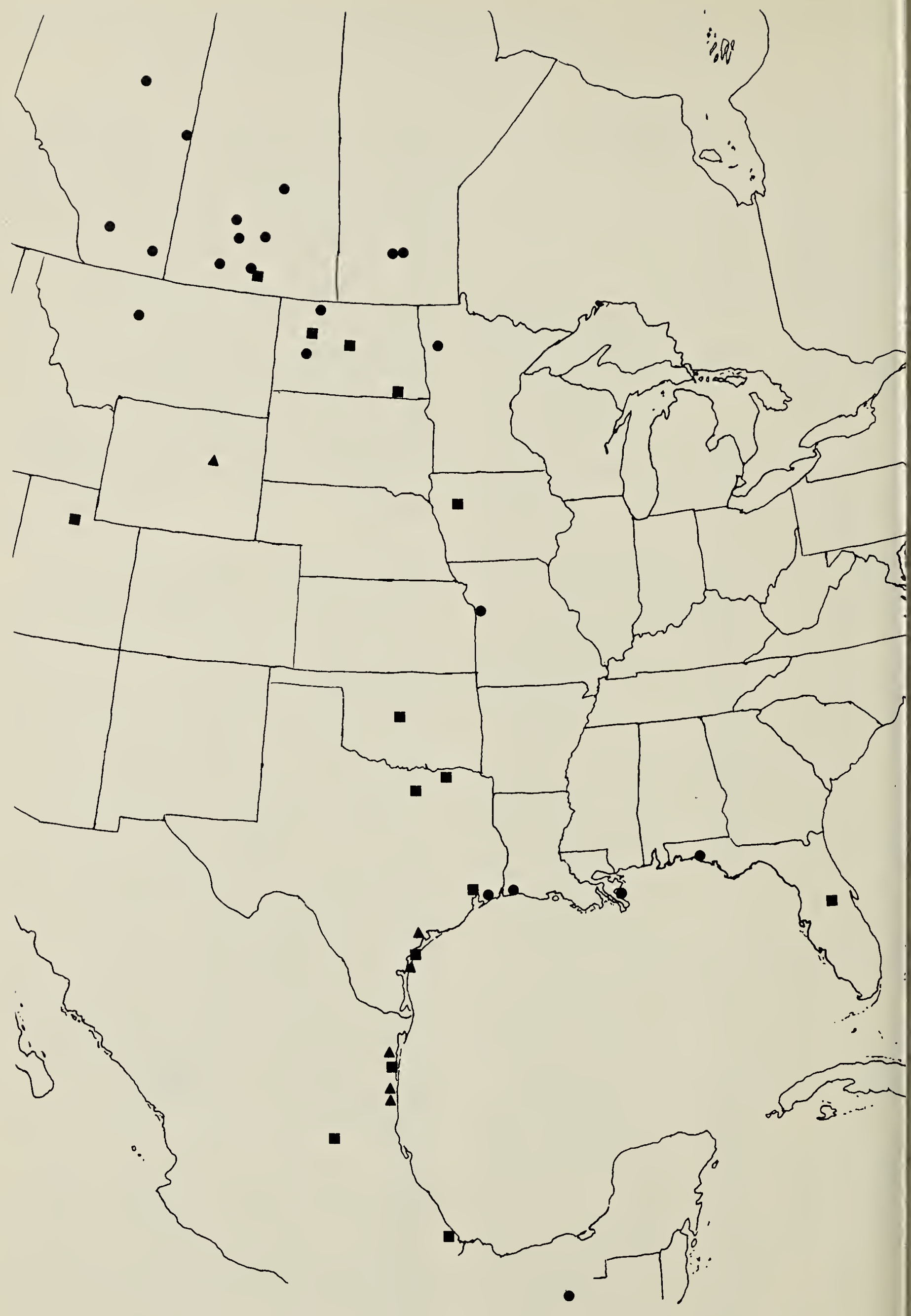

Fig. 2. Recoveries of White Pelicans banded at Old Wives Lake by Fre G. Bard, 1958. Note: squares represent direct recoveries (same year); triangle - January 1 to June 30 of the following year; circles - more than one year olc 


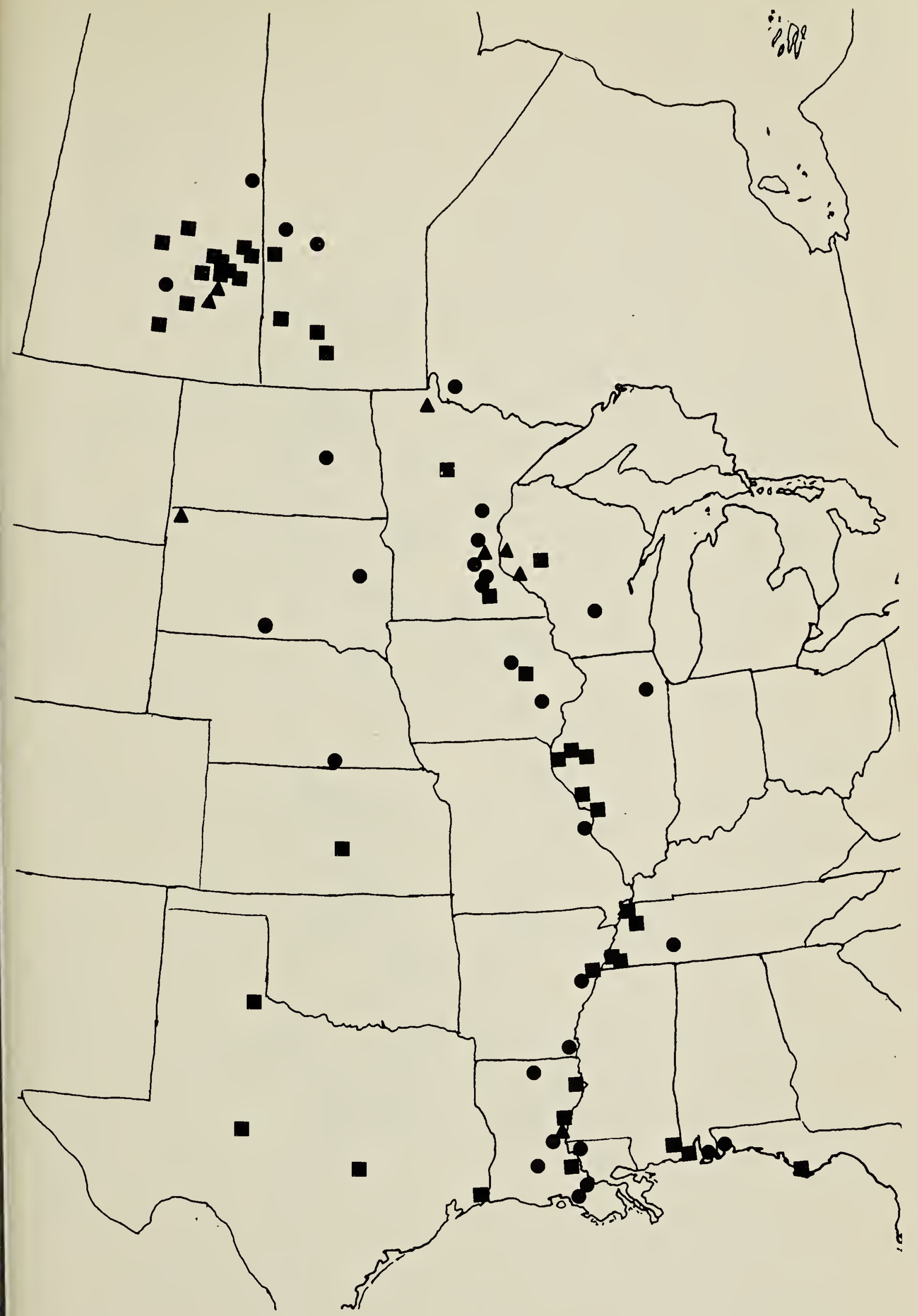

Fig. 3. Recoveries of Double-crested Cormorants banded at Quill Lake by Fred G. Bard, 1931, 1932, 1935, 1936. Note: squares represent direct recoveries (same year); triangles - January 1 to June 30 of following year; circles more than one year old. 


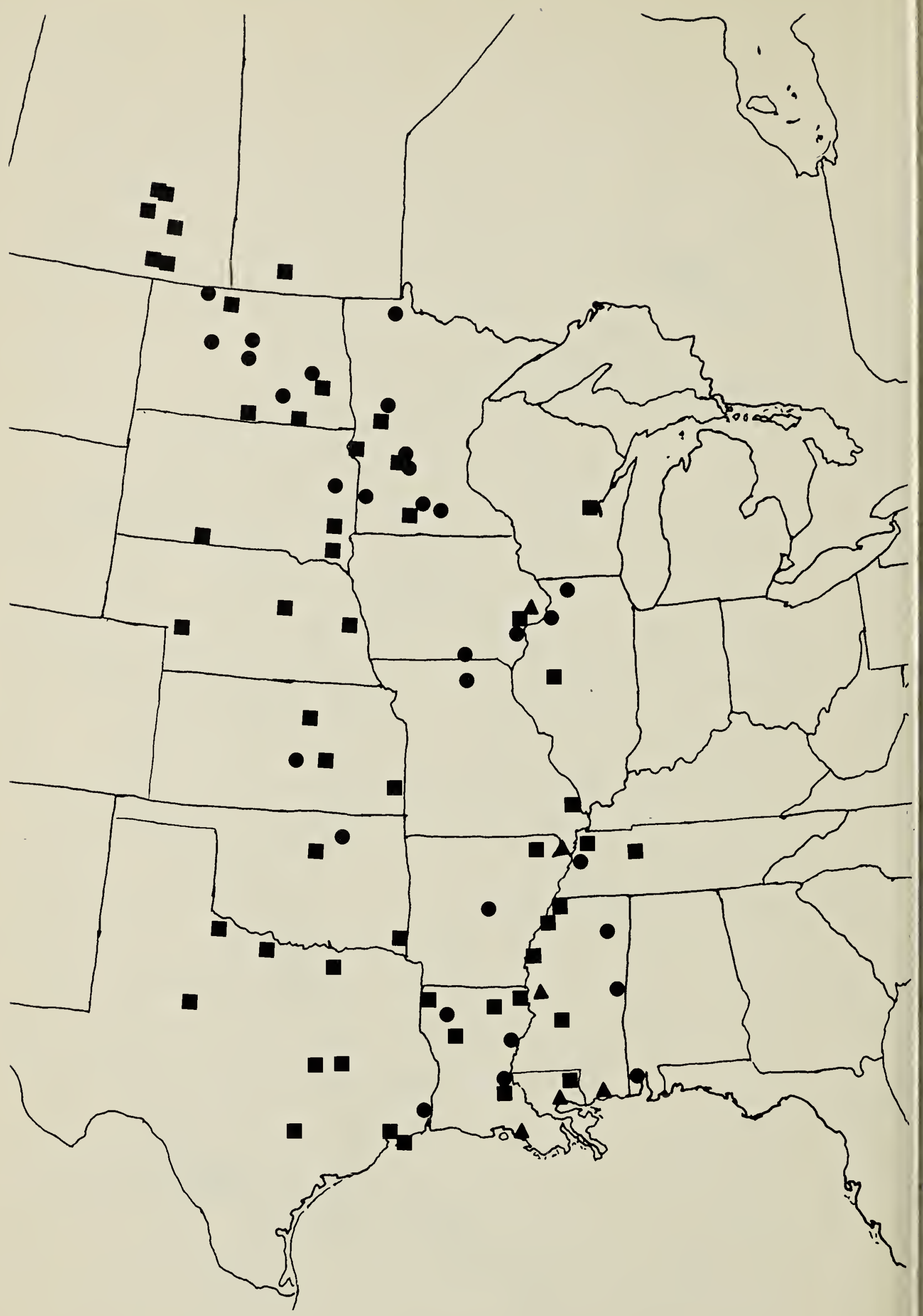

Fig. 4. Recoveries of Double-crested Cormorants banded at Last Mountain Lake by Fred G. Bard, 1934, 1936, 1937. Note: squares represent direct recoveries (same year); triangles - January 1 to June 30 of following year; circles - more than one year old. 


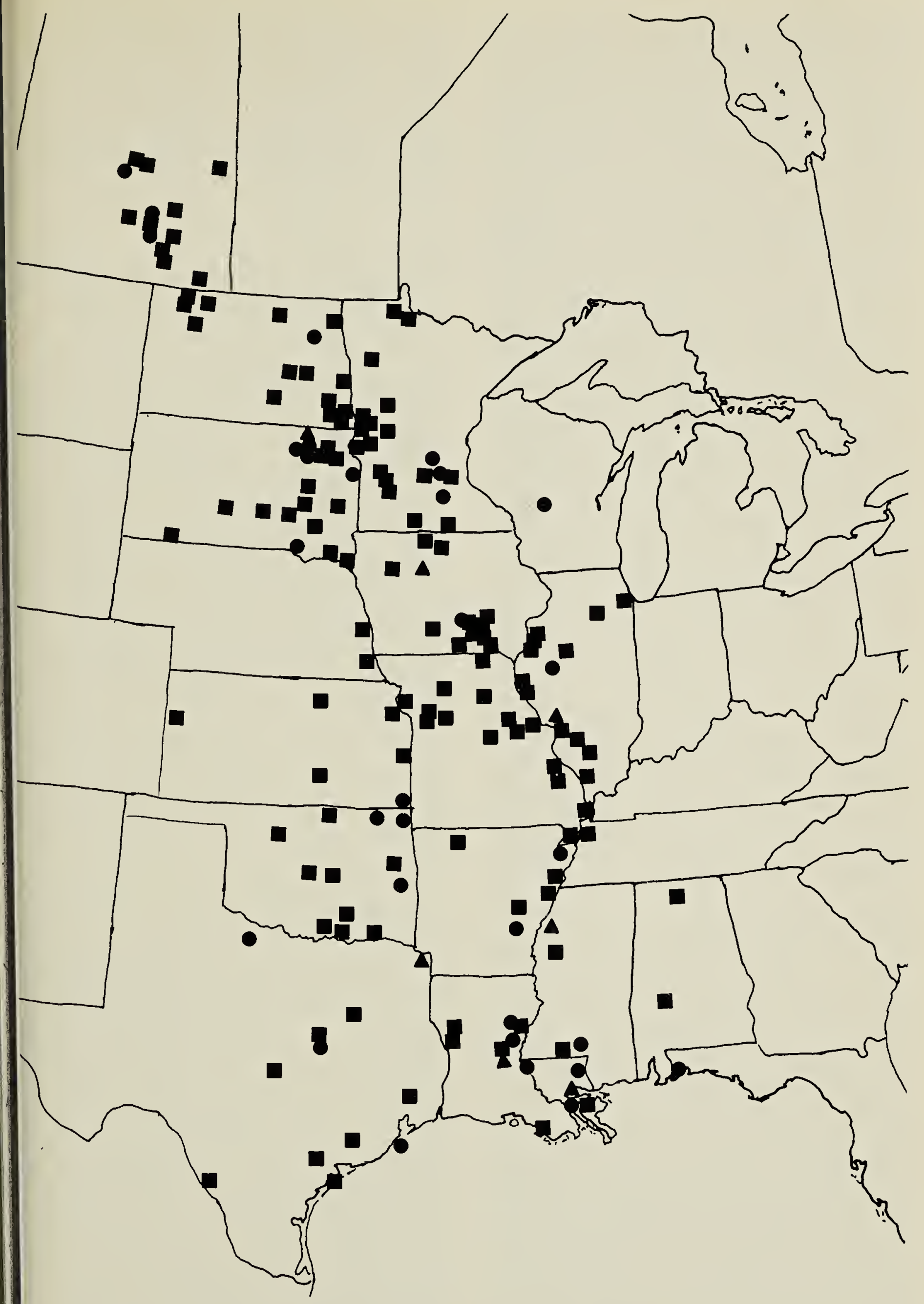

Fig. 5. Recoveries of Double-crested Cormorants banded at Last Mountain Lake by Fred G. Bard, 1938, 1939, 1940, 1948, 1949. Note: squares represent direct recoveries (same year); triangles - January 1 to June 30 of following vear; circles - more than one year old. 
Lake 1938-49. Note that the pelicans from Old Wives tend to go further west than those from Last Mountain and are more likely to be recovered in Alberta, Wyoming, Utah and Mexico, though two crossed over eastward to Florida. Cormorants from both lakes move south along the Mississippi and its tributaries, with no difference between those banded in the early years and later years. (Observers in the Illinois River valley and in $\mathrm{W}$ isconsin noted a change in the migration of cormorants, with a sudden decline in their numbers, beginning after 1950).

One of Bard's White Pelicans appears to hold the world longevity record for this species. 378-00930 was placed on a flightless young pelican at Imperial Beach at the north end of Last Mountain Lake on July 9, 1948. It was found dead of starvation at Big Stone City, South Dakota on October 12, 1960, 12 years, 3 months and 3 days after banding. (The previous record was 10 years, 10 months, 9 days: Rydzewski, The Ring 34:177, 1963).

Bard's recoveries of Marsh Hawks (from Washington, $\mathrm{Oklahom} \mathrm{a} \mathrm{and}$ Texas), Robins (Mississippi and Oklahoma), Common Grackles (Minnesota and Louisiana), Common Crows (the entire tier of states from North $\mathrm{Da}$ kota south to Texas), and a Blackcrowned Night Heron have been mapped in previous articles in the Blue Jay. The most impressive recovery was a Franklin's Gull banded July 8, 1938 at Buffalo Pound Lake and recovered from the dead gull on December 15, 1938 in Peru. It was found by Mr. Jose Oliveri E. Hijos at Urcon Hacienda, $8^{\circ} 35^{\prime}$ S., $77^{\circ} 51^{\prime} \mathrm{W}$. Other recoveries of interest include Great Blue Herons shot at Tampico, Tamaulipas, Mexico and Frederick, Oklahoma; a Ferruginous Hawk found dead in Kansas; a Killdeer killed at Annaudville, Louisiana; and a Mourning Dove shot in Louisiana. Flickers travelled to Iowa and Oklahoma, a Barn Swallow was found dead at Luverne, Minnesota, a Brown Thrasher was shot at Scurry, Texas and a Cedar Waxwing was shot at Frankling, Louisiana.
To Fred G. Bard I wish to express my thanks for the loan of his massive files of banding records, my appreciation for the magnificent museum he has left behind on his retirement, and my congratulations on his honorary doctorate. Well done, Dr. Bard!

\section{ANNUAL MAY-DAY BIRD COUNT, SASKATOON, MAY 23, 1970}

\section{by Stan Shadick and J. F. Roy, Saskatoon}

This year, 48 observers in nine parties established a new record of 162 species, five more than on May 24, 1969, when 49 observers recorded 157 species. Conditions were nearly ideal in the morning with occasional shower: and light winds. By mid-afternoon stron westerly winds made birding difficult.

Records of interest include 277 Westerr Grebes compared with 34 in 1969 and 12 in 1968); large numbers of White-rumped Sand pipers (368), Baird's Sandpiper (1210), Stil Sandpiper (1560), and the irregular Buff. breasted Sandpiper (107). The highest tally for any single species was for the Northery Phalarope, 3,978 having been counted. The Short-eared Owl was again scarce, only on bird was counted (the same as in 1968 compared with last year's total of 32 . Chest nut-collared Longspurs appear to be increasing in recent years; a record high of 271 wer observed.

WEATHER: Temperature at 4:00 a.m. $57^{\circ}$; high during the day, $75^{\circ}$; at 9:00 p.m. $61^{\circ}$. Sky overcast to cloudy. Winds W to NW 10-15 mph with gusts to 24 in the afternoon Rainfall 0.05".

SPECIES LIST (1969 numbers in brackets) : Common Loon 1 (2) ; Rednecked Grebe 6 (4) ; Horned Grebe 130 (102); Eared Grebe 108 (35); Western Grebe 277 (34); Pied-billed Grebe, 17 (13) ; White Pelican, 7 (0) ; Great Blue Heron 3 (4); Black-crowned Night Heron $2(0)$; American Bittern 8 (1); Whistling Swan 2 (1); White-fronted Goose 3 (5); Canada Goose 8 (0); Mallard 225 (222); Gadwall 85 (82); Pintail 224 (220); Green-winged Tea 82 (53); Blue-winged Teal 220 (170) American Widgeon 196 (142); Shoveler 213 (200); Redhead 115 (84); Ringnecked Duck 20 (22); Canvasback 183 (106) ; Lesser Scaup 238 (165) ; Common Goldeneye 14 (6); Bufflehead 22 (28);Ruddy Duck 118 (111); Common Merganser 4 (1); Turkey Vulture 2 (0); Sharp-shinned Hawk 1 (1); Cooper's Hawk 2 (5); Red-tailed Hawk 